\title{
Effect of Intravenous Infusion of a 7.2\% Hypertonic Saline Solution on Serum Electrolytes and Osmotic Pressure in Healthy Beagles
}

\author{
Tadaharu AJITO, Kazuyuki SUZUKI and Shigehiro IWABUCHI \\ Central Research Laboratories, Nippon Zenyaku Kogyo Co., Ltd. 1-1 Aza Tairanoue, Asakamachi, Sasagawa, Koriyama, Fukushima \\ 963-0196, Japan
}

(Received 12 August 1998/Accepted 2 February 1999)

\begin{abstract}
The effect of an intravenous (IV) infusion of hypertonic saline solution (HSS; $7.2 \%, 2,400 \mathrm{mOsmol} / \mathrm{kg} \cdot \mathrm{H}_{2} \mathrm{O}$ ) was evaluated by serum electrolyte concentrations and osmotic pressure in the anesthetized beagles. Sixteen beagles were assigned to 3 experimental groups $(2.5,5$ or $15 \mathrm{ml} / \mathrm{kg}$ of HSS IV infusion) or a control group $(5 \mathrm{ml} / \mathrm{kg}$ of isotonic saline solution (ISS) IV infusion) and were monitored for $120 \mathrm{~min}$ after the initiation of fluid infusion. The relative plasma volume (rPV) in the $5 \mathrm{ml} / \mathrm{kg}$ and $15 \mathrm{~m} l / \mathrm{kg} \mathrm{HSS} \mathrm{groups}$ progressively expanded to $143.1 \pm 7.4 \%$ at $3 \mathrm{~min}$ and $156.4 \pm 5.9 \%$ at $5 \mathrm{~min}$ after the initiation of the fluid infusion, respectively. Significant increases were not produced by ISS and $2.5 \mathrm{ml} / \mathrm{kg}$ HSS infusion. The serum sodium and chloride concentrations in the ISS group were not altered. The $5 \mathrm{~m} / \mathrm{kg}$ HSS infusion induced transient high osmotic and sodium levels, and the serum sodium concentration remained under the $160 \mathrm{mM} / \mathrm{l}$ after the completion of the HSS infusion. However, the $15 \mathrm{~m} l / \mathrm{kg}$ HSS infusion induced a constant high osmotic level (340.5-352.8 mOsmol/ $\left./ \mathrm{kg} \cdot \mathrm{H}_{2} \mathrm{O}\right)$ and hypernatremia $(161.4-174.5 \mathrm{mM} / \mathrm{l})$ from 10 to $90 \mathrm{~min}$ after the initiation of the fluid infusion. The $15 \mathrm{ml} / \mathrm{kg}$ HSS infusion induced significant decreases in the partial pressure of oxygen $\left(\mathrm{PaO}_{2}\right)$, reaching $63.7 \pm 8.0 \mathrm{mmHg}$ at $120 \mathrm{~min}$ after the initiation of the fluid infusion compared with an immediately before fluid infusion value. On the basis of these findings, $5 \mathrm{ml} / \mathrm{kg}$ HSS infusion can be safely administered to healthy beagles for expanding the plasma volume without inducing hypernatremia. A $5 \mathrm{ml} / \mathrm{kg}$ HSS infusion is thus recommended for the initial field resuscitation of dogs. - KEY wORDs: arterial blood pressure, canine (beagle), hypernatremia, hypertonic saline solution, plasma volume.
\end{abstract}

J. Vet. Med. Sci. 61(6): 637-641, 1999

The beneficial effects of a 7.2\% hypertonic saline solution (HSS; $2,400 \mathrm{mOsmol} / \mathrm{kg} \cdot \mathrm{H}_{2} \mathrm{O}$ ) on cardiopulmonary function in dogs with hemorrhage shock [9, 10, 14, 15, 23] were reported. Several possibilities concerning the mechanisms of beneficial effects of a HSS intravenous (IV) infusion have been proposed, as follows. One possibility is the expansion of circulating volume $[2,3,8,10,13,14,18-$ 20]. A $140 \mathrm{~m} l$ infusion of HSS can drew $575 \mathrm{ml}$ and 285 $\mathrm{m} l$ of water from interstitial and intracellular fluid compartments, respectively; the expanding plasma volume thus reached $1,000 \mathrm{~m} l$ [8]. Second possibility is that hypertonic electrolyte solutions have positive intropic effects $[4,15,22,23]$. The increasing cardiac output is apparently mediated by a reflex arc involving the vagus nerve with receptor in the lung $[13,15,23]$. In addition, mean arterial pressure (MAP) is restored, and peripheral and pulmonary vascular resistance are reduced $[1,11,12,15,16]$. These beneficial effects of HSS infusion most likely result from an increase in preload, a decrease in afterload, or both. The HSS may be valuable in the initial management of dogs with hypovolemic shock, because of its rapid resuscitative effects.

HSS causes considerable increases in serum sodium and chloride concentrations as well as serum osmotic pressure when administered to dogs. Cerebral edema may occurs a consequence of rapid $\mathrm{NaCl}$ administration, and sodium concentrations in the cerebrospinal fluid or serum greater than $160 \mathrm{mM} / l$ can be diagnosed as salt poisoning [21]. Therefore, the rapid infusion of HSS should be tested for safety before being recommended for the treatment of dog.
However, no report exist on the safety of an intravenous infusion of HSS to dogs.

Experiments reported here were conduced to determine whether HSS can be administered to dogs without severe biochemical changes, or arterial blood pressure changes with hypernatremia.

\section{MATERIALS AND METHODS}

Experiments were performed on 12 healthy male and 4 female 8 -month-old beagles weighing $8.0 \pm 0.5 \mathrm{~kg}$. The beagles were deemed healthy on the basis of the results of a physical examination, electrocardiograph, and hematological analysis. The dogs were housed individually under controlled temperature $\left(23^{\circ} \mathrm{C}\right)$ and lighting (12 hr light on) in a well-ventilated room. A complete, balanced chow consisting of pelleted food (Original, Iams Japan Co., Tokyo, Japan) and fresh water were available ad libitum.

Each dog was anesthetized with xylazine hydrochloride (2.5 $\mathrm{mg} / \mathrm{kg}$ of body weight, IM; Seduluck-2\%, Nippon Zenyaku Kogyo Co., Fukushima, Japan) and ketamine hydrochloride $(10 \mathrm{mg} / \mathrm{kg}$ of body weight, IM; Ketalar 50 , Sankyo, Tokyo) after a subcutaneous administration of atropine sulfate $(0.05 \mathrm{mg} / \mathrm{kg}$ of body weight; Tanabe Seiyaku Co., Osaka, Japan). A 22-gauge IV catheter (Safelet Cath; Nipro Co., Osaka) was inserted percutaneously into the left cephalic vein, and the free end of the catheter was connected to an original drip tube (15 drops equal one $\mathrm{m} l$; Nipro Co.). The anesthesia was controlled with ketamin chloride dissolved in 5\% dextrose solution by an IV infusion 
via the cephalic vein catheter. Three 14-gauge, $30 \mathrm{~cm}$-long catheters (Safelet Cath; Nipro Co.) were inserted into the right femoral artery and vein, and jugular vein, respectively. The catheters in the right jugular and femoral veins were used for fluid infusion and collection of venous blood sample, respectively. The arterial catheter was connected to a strain-gauge transducer (DX-360; Nihon Kohden Co., Tokyo) coupled to a galvanometric recorder (Nippon Colin Co., Aichi, Japan). Rectal temperature was also monitored by use of a galvanometric recorder throughout the experimental period.

After preparations were completed, dogs were monitored for $15 \mathrm{~min}$ to ensure hemodynamic stability. The time of the initiation of the HSS or isotonic saline solution $(0.9 \%$ $\mathrm{NaCl}$, ISS) infusion (IV, at a flow rate of $1.6 \mathrm{~m} / \mathrm{kg} / \mathrm{min}$ ) was designated as $0 \mathrm{~min}$. The 16 beagles were randomly assigned to the ISS group (4 beagles; IV infusion of $5 \mathrm{ml}$ $\mathrm{kg}$ ISS) or one of 3 HSS groups (4 beagles per group; IV infusion of $2.5,5$ or $15 \mathrm{ml} / \mathrm{kg}$ of HSS). The fluid infusion time for the $2.5,5$ and $15 \mathrm{ml} / \mathrm{kg}$ groups were $1.5,3$ and 9 min when the fluid was infused IV at a flow rate of $1.6 \mathrm{~m} /$ / $\mathrm{kg} / \mathrm{min}$, respectively. All beagles were monitored until 120 min, at the time they were allowed to recover from anesthesia in individual cages.

Arterial and venous blood samples were collected at 0,3 , $5,15,30,60,90$ and $120 \mathrm{~min}$ after the infusion of HSS or ISS. Immediately before the collection of each blood sample, the heart rate (HR), systolic arterial pressure (SAP), mean arterial pressure (MAP), diastolic arterial pressure (DAP) and rectal temperature were recorded. Arterial blood samples were collected anaerobically in heparinized one $\mathrm{m} l$ syringes, and the tips of the syringes were capped. Immediately after collection, these samples were analyzed for $\mathrm{pH}$ and blood gases by use of an automatic gas analyzer (model 248 pH/gas analyzer; Ciba Corning Diagnostic, Excess, England, UK) at $37^{\circ} \mathrm{C}$. Values were automatically corrected by the values of rectal temperature. Some venous blood samples were used to determine hemoglobin concentration (Hb; Sysmex F-800; R. A. System Co., Nagano, Japan) and hematocrit value (Ht). Other blood samples were stored in test tubes and centrifuged, and serum was harvested and stored at $-20^{\circ} \mathrm{C}$ until assayed.

Changes in the relative plasma volume (rPV) were calculated from $\mathrm{Hb}$ and $\mathrm{Ht}$, using accepted formulas [7, 1820]. The serum osmotic pressure was determined by the freezing point depression method, using a one-ten osmometer (Fiske Association, Norwood, MA, U.S.A.). Serum sodium and potassium concentrations were determined by a flame photometer (model 480 flame photometer; Ciba Corning Diagnostic). The serum chloride concentration was analyzed by the electrode method, using an automatic chloride analyzer (model 925 chloride analyzer; Ciba Corning Diagnostic).

Data are presented as mean \pm SD. Measured dependent variables were compared among the four groups for each sample collection period, using repeated-measures ANOVA. Within groups, mean values for each dependent variable were compared with the 0 min values, using repeatedmeasures ANOVA. A value of $\mathrm{p}<0.05$ was considered significant.

\section{RESULTS}

Figure 1 shows the sequential changes in the serum sodium, chloride concentrations and osmotic pressure in the beagles given resuscitation fluids. In the ISS group, the serum sodium, potassium and chloride concentrations were not altered by the ISS infusion. The 2.5 and $5 \mathrm{ml} / \mathrm{kg}$ HSS infusions induced transient high sodium levels $(153.9 \pm 2.3$ at 3 and $165.0 \pm 11.3 \mathrm{mM} / l$ at $5 \mathrm{~min}$ after the initiation of the fluid infusion, respectively), and the serum sodium concentrations remained under the $160 \mathrm{mM} / l$ level after the completion of the HSS infusion. In contrast, the serum sodium concentration in the $15 \mathrm{ml} / \mathrm{kg}$-HSS group induced constant hypernatremia $(161.4 \pm 6.6$ to $174.5 \pm 2.3 \mathrm{mM} / \mathrm{l})$ from 10 to $90 \mathrm{~min}$ after the initiation of the fluid infusion. This increase in sodium concentration was significantly

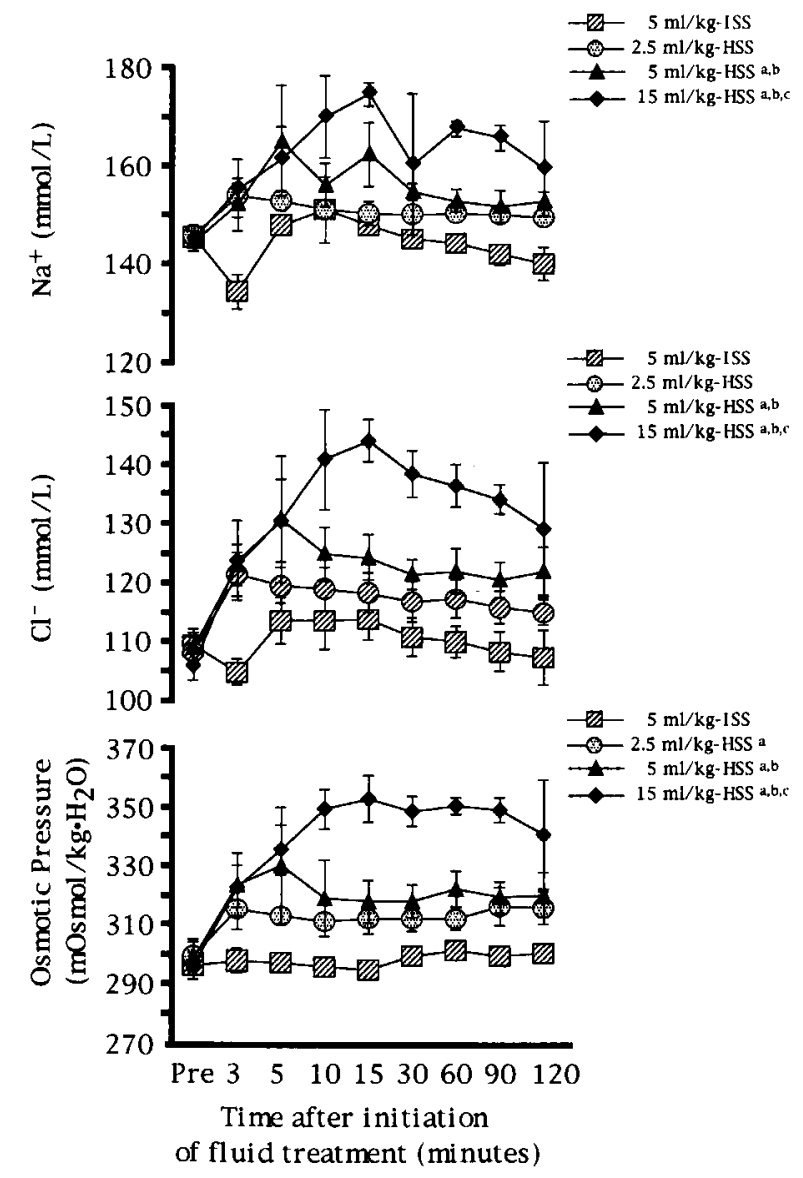

Fig. 1. Sequential changes in serum sodium (Na), chloride concentrations $(\mathrm{Cl})$ and osmotic pressure caused by HSS administration in beagles. Level of significance $(\mathrm{p}<0.05)$ indicated: a: vs $5 \mathrm{ml} / \mathrm{kg}$ ISS, b: vs $2.5 \mathrm{ml} / \mathrm{kg}$ HSS and c: vs 5 $\mathrm{m} l / \mathrm{kg}$ HSS. Data are mean \pm SD of four dogs per group, here and in Fig. 2. 
higher than those in the other three groups $(\mathrm{p}<0.05)$. The 2.5 and $5 \mathrm{ml} / \mathrm{kg}$ HSS infusions induced transient high chloride levels $(121.5 \pm 3.7$ at 3 and $130.7 \pm 10.7 \mathrm{mM} / l$ at 5 min after the initiation of the fluid infusion, respectively). In contrast, the serum chloride concentration in the $15 \mathrm{ml}$ kg-HSS group induced constant hyperchloremia (129.0 \pm 11.2 to $144.0 \pm 3.6 \mathrm{mM} / l)$ from $5 \mathrm{~min}$ to the end of the experiment $(120 \mathrm{~min}$ after the initiation of the fluid infusion). This increase in chloride concentration was significantly higher than those in the other three groups $(\mathrm{p}<0.05)$.

The serum osmotic pressure was not altered by the ISS infusion and remained constant throughout the experiment period. The 2.5 and $5 \mathrm{ml} / \mathrm{kg}$-HSS infusions induced transit hyperosmolality $(315.3 \pm 7.2$ at $3 \mathrm{~min}$ or $330.0 \pm 20.0$ $\mathrm{mOsmol} / \mathrm{kg} \cdot \mathrm{H}_{2} \mathrm{O}$ at $5 \mathrm{~min}$ after the initiation of the fluid infusion, respectively), and the serum osmotic pressures in both groups remained under the $320 \mathrm{mOsmol} / \mathrm{kg} \cdot \mathrm{H}_{2} \mathrm{O}$ level for the rest of the experiment. In contrast, the serum osmotic pressure in the $15 \mathrm{~m} / / \mathrm{kg}$-HSS group was significantly increased during the HSS infusion and remained constant at a level between $352.8 \pm 7.8$ and $340.5 \pm 18.5 \mathrm{mOsmol} /$ $\mathrm{kg} \cdot \mathrm{H}_{2} \mathrm{O}(\mathrm{p}<0.05)$.

The HSS infusion induced a significant decrease in the serum potassium concentrations in the $2.5 \mathrm{~m} l / \mathrm{kg}(4.2 \pm 0.3$ $\mathrm{mM} / l ; 5 \mathrm{~min}$ after the initiation of the fluid infusion), $5 \mathrm{ml}$ $\mathrm{kg}(3.8 \pm 0.0 \mathrm{mM} / l ; 5 \mathrm{~min}$ after the initiation of the fluid infusion) and $15 \mathrm{~m} l / \mathrm{kg}$-HSS groups $(3.6 \pm 0.2 \mathrm{mM} / l ; 10$ min after the initiation of the fluid infusion), which then recovered to the 0 min levels $(4.8 \pm 0.2,4.8 \pm 0.2$ and $4.8 \pm$ $0.4 \mathrm{mM} / l$, respectively; $\mathrm{p}<0.05)$.

The arterial blood $\mathrm{pH}$, partial pressure of carbon dioxide, ionized bicarbonate concentration and base excess in all four groups were not altered by the resuscitation fluid infusion. The $\mathrm{PaO}_{2}$, and $\mathrm{O}_{2}$ sat in the ISS group was slightly but not significantly decreased. In the $2.5 \mathrm{~m} l / \mathrm{kg}$-HSS group, these values remained at 0 min levels. No significant differences were observed in these values between the ISS and $2.5 \mathrm{~m} l / \mathrm{kg}$-HSS groups. The $5 \mathrm{ml} / \mathrm{kg}$-HSS infusion induced significant increases in the $\mathrm{PaO}_{2}$, and $\mathrm{O}_{2}$ sat, and the increased $\mathrm{PaO}_{2}$, and $\mathrm{O}_{2}$ sat in this group were maintained for the rest of the experiment. The $15 \mathrm{ml} / \mathrm{kg}$-HSS infusion, in contrast, induced progressive decreases in $\mathrm{PaO}_{2}$ and $\mathrm{O}_{2}$ sat compared to the 0 values, reaching $63.7 \pm 8.0 \mathrm{mmHg}$ and $85.8 \pm 5.7 \%$ at $120 \mathrm{~min}$ after the initiation of the fluid infusion, respectively.

Figure 2A shows the sequential changes in the rPV and serum osmotic pressure in the beagles given resuscitation fluids. No significant differences were observed in the rPV between the ISS and $2.5 \mathrm{ml} / \mathrm{kg}$-HSS groups. The rPVs in the 5 and $15 \mathrm{ml} / \mathrm{kg}$-HSS groups showed a progressive increase to $143.1 \pm 7.4 \%$ at $3 \mathrm{~min}$ and $156.4 \pm 5.9 \%$ at 5 min after the initiation of the fluid infusion, respectively. The expanding plasma volume in the $5 \mathrm{ml} / \mathrm{kg}$-HSS group remained at a higher level than that at 0 value, but did not in the $15 \mathrm{ml} / \mathrm{kg}$-HSS group.

The heart rate (HR) in the ISS and $2.5 \mathrm{ml} / \mathrm{kg}$-HSS groups
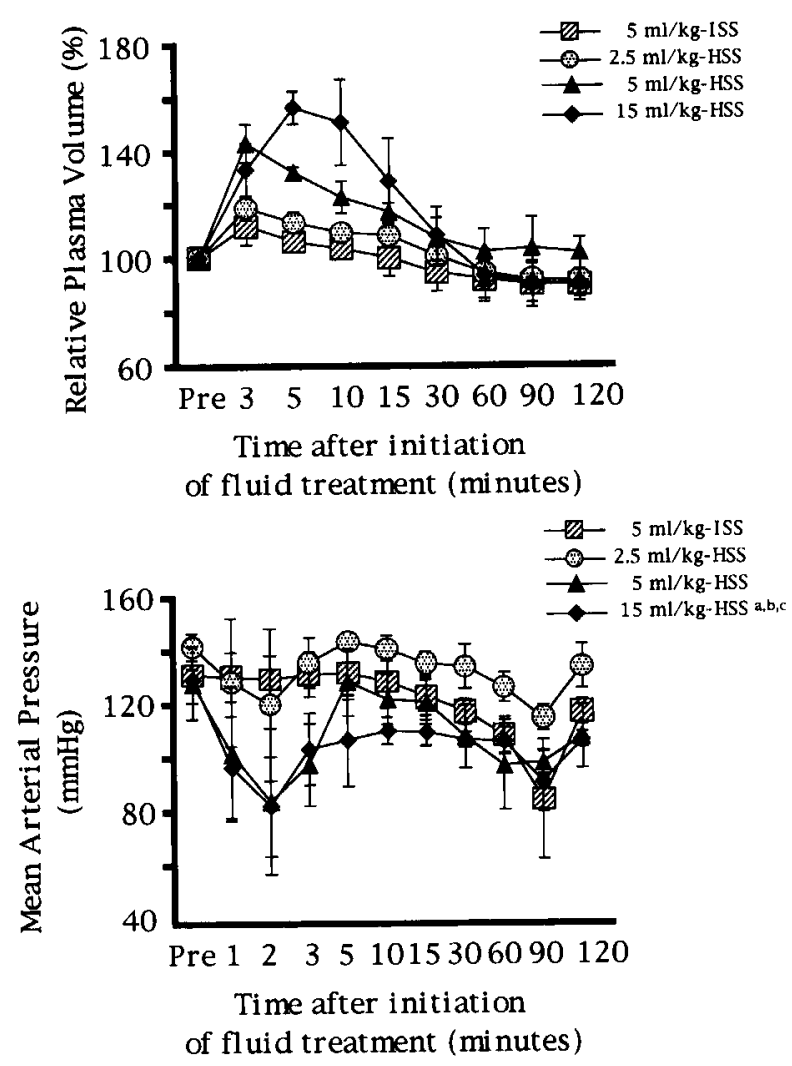

Fig. 2. Sequential changes in relative plasma volume (rPV) and mean arterial pressure (MAP) caused by HSS infusion in beagles. The rPV values were calculated from $\mathrm{Hb}$ and $\mathrm{Ht}$, using Greenleaf's formulas [7, 18]. Level of significance ( $<<0.05$ ) indicated: a: vs $5 \mathrm{ml} / \mathrm{kg}$ ISS, b: vs $2.5 \mathrm{ml} / \mathrm{kg}$ HSS and c: vs $5 \mathrm{ml} / \mathrm{kg}$ HSS.

was not significantly different from the pre-infusion values. The HR of the $5 \mathrm{ml} / \mathrm{kg}$-HSS group was transiently but significantly increased, reaching $144.0 \pm 5.2$ beats $/ \mathrm{min}$ at 3 min after the initiation of the fluid infusion, from pre infusion value of $125.5 \pm 14.9$ beats $/ \mathrm{min}(\mathrm{p}<0.05)$. For the $15 \mathrm{ml} / \mathrm{kg}$-HSS group, a progressive and significant increase in HR was observed during the infusion period, reaching $185.8 \pm 13.6$ beats/min, and the increased HR remained until $60 \mathrm{~min}$ after the initiation of the fluid infusion (155.0 \pm 15.9 beats/min). This increase was significantly greater than that for the $5 \mathrm{ml} / \mathrm{kg}$-HSS group. Figure $2 \mathrm{~B}$ shows the sequential changes in MAP in the beagles given resuscitation fluids. The MAP in the ISS and $2.5 \mathrm{ml} / \mathrm{kg}$-HSS groups remained constant at the pre infusion level during the experiment. In contrast, the MAP in the 5 and $15 \mathrm{ml} / \mathrm{kg}$ HSS groups showed significantly decreases, from $142.5 \pm$ 1.3 and $142.5 \pm 3.1 \mathrm{mmHg}$ as 0 min values to $100.3 \pm 26.3$ and $97.0 \pm 17.6 \mathrm{mmHg}$ as $2 \mathrm{~min}$ after the initiation of the fluid infusion values, respectively. The decreased MAP in the those two groups remained at values lower than those at 0 min value $(\mathrm{p}<0.05)$. In a similar manner, SAP and DAP in the beagles given 5 or $15 \mathrm{~m} / \mathrm{kg}$-HSS were significantly decreased at 2 min after the initiation of the fluid infusion, 
and then remained at low levels compared with values at pre value.

\section{DISCUSSION}

The HSS generates an osmotic plasma expansion and increases plasma volume. Since sodium is largely confined to the extracellular compartment, HSS expands the extracellular fluid space by extracting water from the cells. However, a rapid increase in the serum sodium concentrations causes salt poisoning. The diagnosis of salt poisoning is usually based on an increased serum or cerebrospinal fluid sodium concentration in the heifers $(>160 \mathrm{mM} / l)$ [19]. Here, the administration of 2.5 or $5 \mathrm{ml} /$ $\mathrm{kg}$ of HSS produced transient high sodium levels, and the serum sodium concentrations remained under the $160 \mathrm{mM} /$ $l$ level. Those value is limited of the reference range for the serum sodium concentration and was not likely to put the beagles at risk for adverse effect, cf hypernatremia. In contrast, the 3 -fold volume of HSS $(15 \mathrm{ml} / \mathrm{kg})$ reached, the maximal concentration $174.5 \pm 2.3 \mathrm{mM} / l$, at the $15 \mathrm{~min}$ after the initiation of the fluid infusion. The serum level in this group then remained constant at a high level (> 160 $\mathrm{mM} / l$ ) from 10 to $90 \mathrm{~min}$ after the start of the HSS infusion. Those values $(>160 \mathrm{mM} / l)$ were likely to have put the beagles at risk for hypernatremia.

In this study, increases in $\mathrm{PaO}_{2}$ were observed in the 5 $\mathrm{ml} / \mathrm{kg}$-HSS group, whereas the $15 \mathrm{ml} / \mathrm{kg}$ HSS infusion caused a progressive decrease in $\mathrm{PaO}_{2}$, which reached 63.7 $\pm 8.0 \mathrm{mmHg}$ at the end of the experiment. A previous study of heifers [20] demonstrated that a large volume of HSS infusion induced decreases in $\mathrm{PaO}_{2}$ accompanied by an accelerating HR. This pulmonary response, therefore, may be caused by a decrease in pulmonary circulation.

The HR of the $5 \mathrm{ml} / \mathrm{kg}$-HSS group was significantly increased but transient. However, the $15 \mathrm{ml} / \mathrm{kg}$-HSS group, a progressive and significant increase in HR was observed during the infusion period, reaching $185.8 \pm 13.6$ beats $/ \mathrm{min}$. Although the ketamine hydrochloride induced an acceleration of the HR, results in this study demonstreated that the large volume of the HSS thus induced an accelerating HR, and then accelerating HR may induce a decrease in stroke volume. Therefore, use of the large volume of the HSS to resuscitation of the dogs with hypovolemic shock were not recommended.

In the present study, one to two min after the initiation of the fluid infusion, the arterial blood pressure parameters (SAP, MAP and DAP) in the $5 \mathrm{ml} / \mathrm{kg}$ and $15 \mathrm{ml} / \mathrm{kg}-\mathrm{HSS}$ groups were progressively decreased, but transient. It was reported that transient decreases in the SAP of heifers given $5 \mathrm{ml} / \mathrm{kg}$-HSS occurred immediately the start of the after HSS infusion [20]. Although arterial blood pressure was decreased at the immediately after the HSS infusion, there are many reports that the use of HSS has successfully restored cardiovascular function, especially arterial blood pressure, in dogs and cats with hemorrhagic or hypovolemic shock [5, 6, 9-11, 14, 15, 23]. This phenomenon may have been caused by the vagus nerve reflex and expanding plasma volume [15, 23].

Here, however, no changes in the start of the SAP of the dogs that received $2.5 \mathrm{ml} / \mathrm{kg}$ of HSS were observed immediately after the start of the HSS infusion, suggesting that an HSS infusion at less than $5 \mathrm{ml} / \mathrm{kg}$ cannot successfully restore cardiovascular function when used in dogs.

The $\mathrm{rPV}$ in the 5 and $15 \mathrm{ml} / \mathrm{kg}$-HSS groups of the study reported here increased markedly immediately after completion of the HSS infusion, reaching the values of 143.1 $\pm 7.1 \%$ at $3 \mathrm{~min}$ after the initiation of the fluid infusion and $156.4 \pm 5.9 \%$ at $5 \mathrm{~min}$ after the initiation of the fluid infusion, respectively. However, significant increases were not observed in the $2.5 \mathrm{~m} l / \mathrm{kg}$-HSS and ISS groups. Several researchers $[4,22]$ have found an expanding plasma volume to be transient and minimal by $60 \mathrm{~min}$ after the initiation of resuscitation. To prolong the expanding rPV response to HSS, dextran has been added to HSS. However, hypertonic saline-dextran solution does not appear to be required for the resuscitation of dogs, because our analysis of the present results indicates that a $5 \mathrm{ml} / \mathrm{kg}$ HSS infusion without dextran can produce a significantly expansion of the rPV until 120 min after the initiation of the HSS infusion. The expanding plasma volume in the present $5 \mathrm{ml} / \mathrm{kg}$ HSS group remained at level higher than the pre-infusion level for the rest of the experiment, but this did not occur in the other groups.

Although increases in the sodium, chloride and serum osmotic pressure were caused by the $5 \mathrm{ml} / \mathrm{kg}$ HSS infusion, the changes were not of sufficient magnitude to be of risk to the beagles. Therefore, the $5 \mathrm{ml} / \mathrm{kg}$ HSS infusion was found to be safe for use in dogs, when the infusion is given through a jugular vein at the rate of $1.6 \mathrm{ml} / \mathrm{kg} / \mathrm{min}$.

ACKNOWLEDGMENTS. We wish to thank Mr. Hideyuki Anzai for his valuable assistance, and Miss Miki Yamamura for her skillful work in measuring the serum electrolytes concentrations.

\section{REFERENCES}

1. Bertone, J. J., Gossett, K. A., Shoemaker, K. E., Bertone, A. L. and Schneiter, H. L. 1990. Effect of hypertonic vs isotonic saline solution on responses to sublethal Escherichia coli endotoxemia in horses. Am. J. Vet. Res. 51: 999-1007.

2. Bertone, J. J. 1991. Hypertonic saline in the management of shock in horses. The Compendium 13: 665-668.

3. Constable, P. D., Schmall, L. M., Muir, W. W. III. Hoffsis, G. F. and Shertel, E. R. 1991. Hemodynamic response of endotoxemic calves to treatment with small-volume hypertonic saline solution. Am. J. Vet. Res. 52: 981-989.

4. Constable, P. D., Schmall, L. M., Muir, W. W. III. and Hoffsis, G. F. 1991. Respiratory, renal, hematologic, and serum biochemical effects of hypertonic saline solution in endotoxemic calves. Am. J. Vet. Res. 52: 990-998.

5. Constable, P. D., Muir, W. W. III. and Binkley, P. F. 1996. Use of hypertonic saline-dextran solution to resusciate hypovolemic calves with diarrhea. Am. J. Vet. Res. 57: 97-104.

6. Dupe, R., Bywater, R. J. and Goddard, M. 1993. A hypertonic infusion in the treatment of experimental shock in calves 
and clinical shock in dogs and cats. Vet. Rec. 133: 585-590.

7. Greenleaf, J. E., Convertino, V. A. and Mangeseth, G. R. 1979.Plasma volume during stress in man: osmolality and red cell volume. J. Appl. Physiol. 47: 1031-1038.

8. Kirby, R. and Rudloff, E. 1997. The critical need for colloids: Maintaining fluid balance. The Compendium 19: 705-717.

9. Lopes, O. U., Pontieri, V., Rocha E Silva, M. and Velasco, I. T. 1981. Hyperosmotic $\mathrm{NaCl}$ and severe hemorrhagic shock: role of the innervated lung. Am. J. Physiol. 241: H883-H890.

10. Mazzoni, M. C., Borgstrom, P., Arfors, K. E. and Intaglietta, M. 1988. Dynamic fluid redistribution in hyperosmotic resuscitation of hypovolemic hemorrhage. Am. J. Physiol. 255: H629-H637.

11. Muir, W. W. III. and Sally, J. 1989. Small-volume resuscitation with hypertonic saline solution in hypovolemic cats. Am. J. Vet. Res. 50: 1883-1888.

12. Muir, W. W. III. 1990. Small volume resuscitation using hypertonic saline. Cornell Vet. 80: 7-12.

13. Nerlich, M., Gunther, R. and Demling, R. H. 1983. Resuscitation from hemorrhagic shock with hypertonic saline or lactated Ringer's (effect on the pulmonary and systemic microcirculations). Circ. Shock 10: 179-188.

14. Okrasinski, E. B., Krahwinkel, D. J. and Sanders, W. L. 1992. Treatment of dogs in hemorrhagic shock by intraosseous infusion of hypertonic saline and dextran. Vet. Surg. 21: 20-24.

15. Rocha-E-Silva, M., Velasco, I. T., Nogueira-DA-Silva, R. I., Oliveira, M. A., Negraes, G. A. and Oliveira, M. A. 1987. Hyperosmotic sodium salts reverse severe hemorrhagic shock: other solutions do not. Am. J. Physiol. 253: H751-H762.

16 Rowe, G. G., McKenna, D. H., Corliss, R. J. and Silver, S.
1972. Hemodynamic effects of hypertonic sodium chloride. J. Appl. Physiol. 32: 182-184.

17. Smith, G. J., Kramer, G. C., Perron, P., Nakayama,S., Gunther, R. A. and Horcroft, J. W. 1985. A comparison of several hypertonic solutions for resuscitation of bled sheep. J. Surg. Res. 39: 517-528.

18. Suzuki, K., Ajito, T., Kadota, E., Ohashi, S. and Iwabuchi S. 1997. Comparison of commercial isotonic fluids intravenously administered to rehydrate fasted bullocks. J. Vet. Med. Sci. 59: 689-694.

19. Suzuki, K., Ajito, T. and Iwabuchi, S. 1998. Effect of infusion of hypertonic saline solution on conscious heifers with hypoxemia caused by endotoxin infusion. Am. J. Vet. Res. 59: 452-457.

20. Suzuki, K., Ajito, T. and Iwabuchi, S. 1998. Effect of a 7.2\% hypertonic saline solution infusion on arterial blood pressure, serum sodium concentration and osmotic pressure in normovolemic heifers. J. Vet. Med. Sci. 60: 799-803.

21. Tyler, J. W., Welles, E. G., Sorjonen, D. C., Spano, J. S., Gaslin, J. T. and Spears, H. 1993. Cerebrospinal fluid composition of cattle with endotoxin-induced mastitis treated with isotonic $(0.9 \%)$ or hypertonic $(7.5 \%)$ sodium chloride. J. Vet. Int. Med. 7: 91-94.

22. Tyler, J. W., DeGraves, F. J., Erskine, R. J., Riddell, M. G., Lin, H. C. and Kirk, J. H. 1994. Milk production in cows with endotoxin-induced mastitis treated with isotonic or hypertonic sodium chloride solution. J. Am. Vet. Med. Assoc. 204: 1949-1952.

23. Velasco, I. T., Pontieri, V., Rocha E Silva, M. and Lopes, O. U. 1980. Hyperosmotic $\mathrm{NaCl}$ and sever hemorrhagic shock. Am. J. Physiol. 239: H664-H673. 